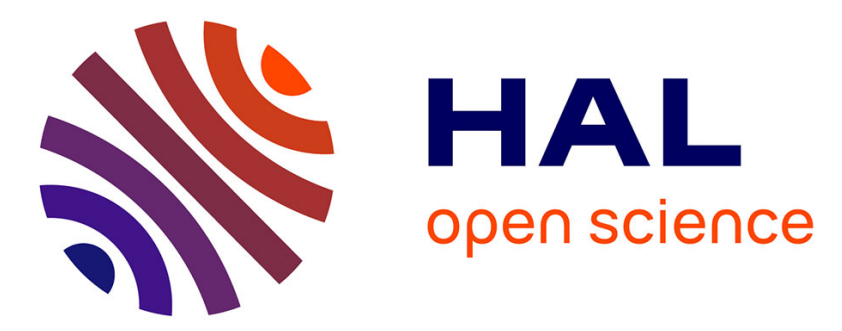

\title{
Body growth and mortality of the spiny lobster Palinurus elephas within and outside a small marine protected area
}

Danièle Bevacqua, Paco Melià, Maria C. Follesa, Giulio Alessandro de Leo, Marino Gatto, Angelo Cau

\section{To cite this version:}

Danièle Bevacqua, Paco Melià, Maria C. Follesa, Giulio Alessandro de Leo, Marino Gatto, et al.. Body growth and mortality of the spiny lobster Palinurus elephas within and outside a small marine protected area. Fisheries Research, 2010, 106 (3), pp.543-549. 10.1016/j.fishres.2010.10.008 . hal02660580

\section{HAL Id: hal-02660580 \\ https://hal.inrae.fr/hal-02660580}

Submitted on 30 May 2020

HAL is a multi-disciplinary open access archive for the deposit and dissemination of scientific research documents, whether they are published or not. The documents may come from teaching and research institutions in France or abroad, or from public or private research centers.
L'archive ouverte pluridisciplinaire HAL, est destinée au dépôt et à la diffusion de documents scientifiques de niveau recherche, publiés ou non, émanant des établissements d'enseignement et de recherche français ou étrangers, des laboratoires publics ou privés. 


\title{
Body growth and mortality of the spiny lobster Palinurus elephas within and outside a small marine protected area
}

\author{
Daniele Bevacqua $^{\mathrm{a}, *}$, Paco Melià ${ }^{\mathrm{b}}$, Maria C. Follesa ${ }^{\mathrm{c}}$, Giulio A. De Leo ${ }^{\mathrm{a}}$, Marino Gatto ${ }^{\mathrm{b}}$, Angelo Cau ${ }^{\mathrm{c}}$ \\ a Dipartimento di Scienze Ambientali, Università degli Studi di Parma, Viale Usberti 33A, I-43100 Parma, Italy \\ ${ }^{\mathrm{b}}$ Dipartimento di Elettronica e Informazione, Politecnico di Milano, Via Ponzio 34/5, I-20133 Milano, Italy \\ c Dipartimento di Biologia Animale ed Ecologia, Università di Cagliari, Viale Poetto 1, I-09216 Cagliari, Italy
}

\section{A R T I C L E I N F O}

\section{Article history:}

Received 22 June 2010

Received in revised form

24 September 2010

Accepted 7 October 2010

\section{Keywords:}

Spiny lobster

Marine protected areas

Body growth

Mark-recapture studies

Mortality rates

\begin{abstract}
A B S T R A C T
Following the establishment of a small marine protected area (MPA) located off western Sardinia (Mediterranean Sea), a long-term survey was conducted on a spiny lobster (Palinurus elephas) population inhabiting the MPA and adjacent fishing grounds. Between 1998 and 2005, median carapace length increased by $1.9 \mathrm{~mm}$ year $^{-1}$ both within and outside the MPA. On the contrary, body size dispersion (IQR) increased by $0.9 \mathrm{~mm}_{\text {year }}{ }^{-1}$ within the MPA and decreased by $0.6 \mathrm{~mm}_{\text {year }}{ }^{-1}$ outside. Mark-recapture data were used to develop and calibrate a body growth model explicitly accounting for sexual dimorphism and inter-individual variability. Median asymptotic carapace length was equal to $116 \mathrm{~mm}$ in females and $185 \mathrm{~mm}$ in males. Age frequency distributions, derived from size distributions through the body growth model, were used to estimate mortality rates inside (ca. 0.41 year $^{-1}$, natural mortality) and outside (ca. 0.78 year $^{-1}$, natural + fishing mortality) the MPA. Results provide new estimates of key life history traits for this species and suggest that the MPA is effective in protecting lobsters despite its small dimensions.

(c) 2010 Elsevier B.V. All rights reserved.
\end{abstract}

\section{Introduction}

A large proportion of marine stocks are currently overexploited, and fishing is considered one of the greatest threats affecting marine biodiversity and ecosystem functions and services (Pauly et al., 2002). Proper conservation measures and sustainable fishing practices can help maintain ecosystem health and related services to humans. From this perspective, marine protected areas (MPAs) have gained popularity in the last decades as a tool to ensure marine biodiversity conservation and replenishment of surrounding fishing grounds (Halpern, 2003; Stelzenmüller et al., 2007; Goñi et al., 2008). Long-term studies are fundamental to assess the effectiveness of protection measures (Russ et al., 2005). In fact, expected benefits of MPAs, including increase in stock abundance, average body size, and spillover of juveniles or reproductive adults may require several years to become evident (McClanahan et al., 2007). In addition, long-term studies provide valuable information to investigate demographic dynamics of protected stocks and derive mathematical models that can eventually be used to forecast the response of key species to different management policies.

Species with moderate mobility and subject to high levels of fishing mortality, such as most lobster species, have shown the strongest responses to protection (Micheli et al., 2004; Goñi et al.,

\footnotetext{
* Corresponding author. Tel.: +39 521 906986; fax: +39 521905402.

E-mail address: daniele.bevacqua@unipr.it (D. Bevacqua).
}

2008). Lobsters, which have relatively small home ranges (Smith et al., 2001; Follesa et al., 2009) and are actively pursued because of their high commercial value (Goñi and Latrouite, 2005), may greatly benefit from the establishment of even small MPAs. Edgar and Barret (1999) documented an extraordinary increase (more than an order of magnitude) of rock lobster biomass after the implementation of the Maria Island reserve, in Tasmania. Lester et al. (2009) investigated the biological effects of no-take marine reserves on different taxonomic groups and showed that lobsters were among those that experienced the most significant benefits (in terms of biomass, density and body size increase) from protection. In this respect, the spiny lobster Palinurus elephas is a very representative model species. P. elephas is intensively exploited in the Mediterranean Sea and the north-eastern Atlantic (Goñi et al., 2003). It is traditionally targeted by artisan fisheries, but the change in fishing strategy (from traps to trammel nets) that took place between the 1960 s and the 1970s has severely impacted lobster populations (Hunter, 1999; Goñi and Latrouite, 2005). Consequently, lobster catches have declined in most of the distribution range during recent decades (Goñi et al., 2003; Goñi and Latrouite, 2005). Despite its high commercial value, almost no long-term surveys have been carried out on P. elephas, with the remarkable exception of those conducted in the Columbretas islands marine reserve (southern Spain; Goñi et al., 2003, 2006, 2010) and in Su Pallosu MPA (western Italy; Follesa et al., 2007a, 2009). Also, few studies have investigated body growth patterns and none of them has explicitly accounted for inter-individual variability. However, key demographic processes, 
such as sexual maturation, fecundity and natural mortality, are size-dependent in a number of aquatic organisms (Caswell, 1989), and a reliable mathematical description of somatic growth is crucial for population analysis, stock assessment, and fishery management (Katsanevakis and Maravelias, 2008). In particular, suitable body growth models can be used to derive information on age structure from data on body size. This allows the estimation of mortality rates also in species lacking reliable age markers, like crustaceans.

In this work we analysed a data set on P. elephas obtained from an 11-year long mark-recapture experiment (1997-2007) conducted within and around Su Pallosu MPA, located off Sardinian coasts, in the western Mediterranean. The objective of the work was twofold: (1) to investigate body growth in P. elephas and develop a stochastic model explicitly accounting for inter-individual variability; (2) to assess the effectiveness of MPA protection, by comparing body size trends inside and outside the MPA since its establishment in 1998 and by estimating and comparing mortality rates within and outside the protection range.

\section{Materials and methods}

\subsection{The species}

P. elephas is distributed throughout the Mediterranean Sea and along the Atlantic coasts between Morocco and south Norway (Hunter, 1999). The lobster inhabits rocky bottoms from near shore to $70-200 \mathrm{~m}$ of depth (Goñi et al., 2006). It is a longliving (maximum estimated age up to 15 year), slow-growing species reproducing once a year between July and September (Goñi and Latrouite, 2005). Adult movement is restricted within ca. $2.5 \mathrm{~km}_{\text {year }}{ }^{-1}$ and is likely linked to reproduction and feeding, with older individuals showing higher site fidelity than juveniles (Goñi and Latrouite, 2005; Follesa et al., 2009). Fishing regulations include an annual 6-month closure from September to February and a minimum landing size that was recently increased from 80 to $90 \mathrm{~mm}$ carapace length (EC Regulation No. 1967/2006).

\subsection{Study site and data collection}

The study took place at Su Pallosu, a small MPA (ca. $4 \mathrm{~km}^{2}$ ) located in western Sardinia, and adjacent fishing grounds, encompassing an area of ca. $5 \mathrm{~km}$ radius from the MPA centre (Fig. 1). Both the MPA and fishing grounds are comprised between the 50- $\mathrm{m}$ and 100- $\mathrm{m}$ isobaths and are characterized by similar coralligenous habitats. A monitoring programme including a long-term mark-recapture experiment was started in the region in 1997 (see Follesa et al., 2007a for further details), before commercial fishing was banned in 1998 (Regional Decree No. 766; 6-5-1998). The MPA was established to protect the stock from overexploitation and possibly enhance nearby catches through spillover. Local fishermen have been actively involved in capturing lobsters outside the MPA. To encourage fishermen collaboration, returned individuals were valued at double their commercial price $\left(70-90 € \mathrm{~kg}^{-1}\right.$ during the study period). Between 1998 and 2005, 3601 lobsters caught in the fishing grounds surrounding the MPA were bought from the fishermen.

Between 1997 and 2007, scientific surveys were carried out also within the MPA and 1675 lobsters were caught inside the area. Boats and fishing gears were the same as those operated by commercial fishermen, i.e. trammel nets $2.8-\mathrm{m}$ high, with mesh sizes of 200 and $30 \mathrm{~mm}$ (inner and outer panels, respectively). Lobsters were sexed, measured (carapace length $L$, in $\mathrm{mm}$ ), tagged with plastic T-bar-type tags inserted dorso-laterally between the first and

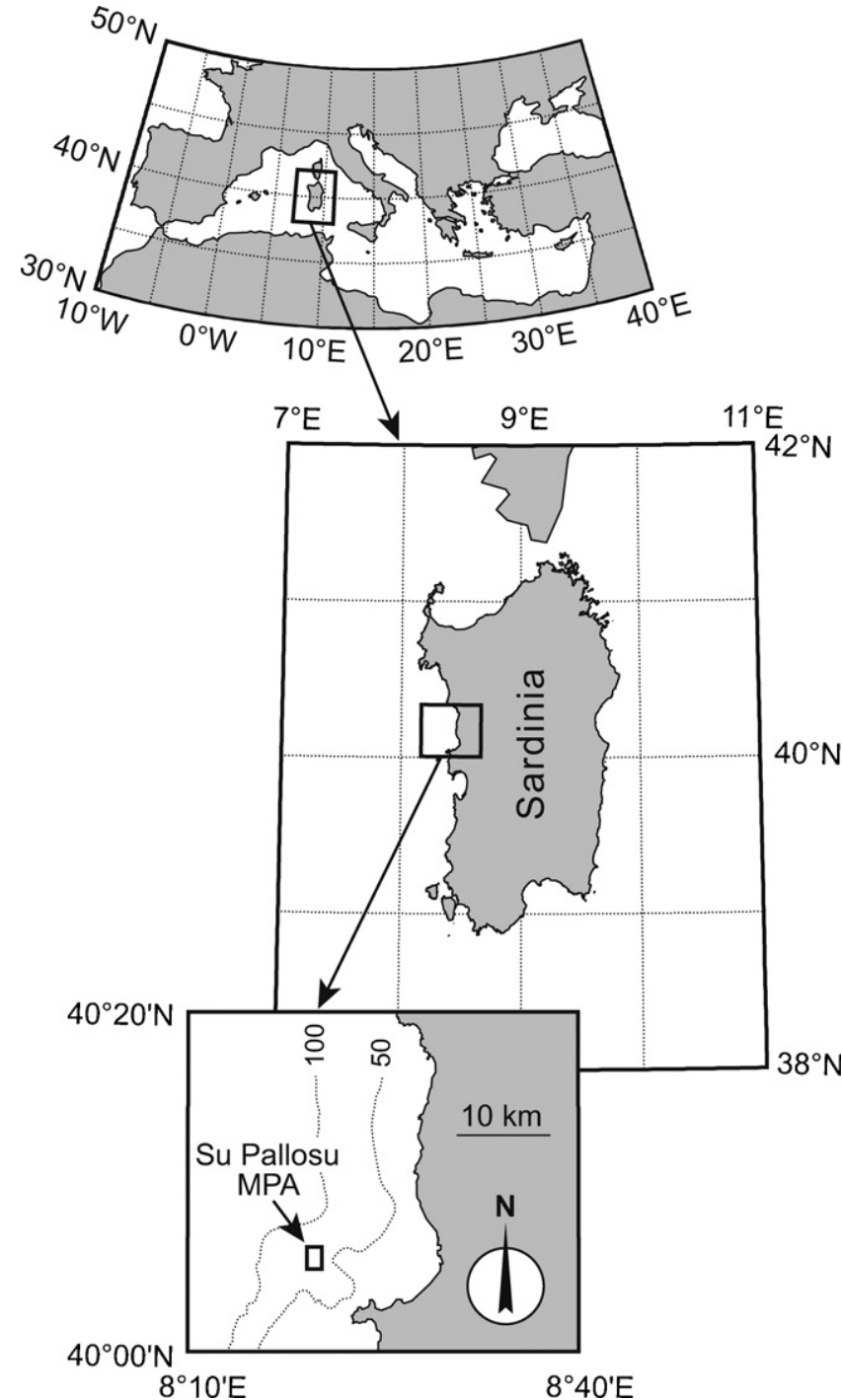

Fig. 1. Su Pallosu marine protected area.

second abdominal segment and eventually released in the centre of the MPA. A summary of the mark-recapture experiment is reported in Table 1 . Recaptured lobsters (347 individuals) were measured to assess body growth and subsequently released in the MPA centre. Only individuals with time at liberty $\geq 1$ year were considered for body growth analysis. This is a common practice in crustaceans showing periodic shedding and aims to exclude individuals captured just before a moult, avoiding a biased estimation of the growth rate (Ulmestrand and Eggert, 2001). The actual sample size used to estimate body growth was therefore reduced to 254 data matching this criterion (107 females and 147 males).

Table 1

Summary of the mark-recapture experiment performed on Palinurus elephas inside and outside Su Pallosu MPA (Sardinia, Italy) between 1997 and 2007.

\begin{tabular}{lll}
\hline & \multicolumn{2}{l}{ Location of first capture } \\
\cline { 2 - 3 } \cline { 2 - 2 } Captured & Inside & Outside \\
\hline Marked & 1675 & 3601 \\
Not recaptured & 1157 & 3515 \\
Recaptured inside $(1 / 2 / 3$ times $)$ & 1068 & 3257 \\
Recaptured outside $(1 / 2 / 3 / 4$ times $)$ & $68 / 8 / 1$ & $114 / 26 / 4$ \\
\hline
\end{tabular}




\subsection{Body size trends}

To assess the effect of protection on lobster size over time, we investigated the link between carapace length $L$ and time of protection (TP), i.e. the time elapsed since the establishment of the MPA. In particular, we wanted to highlight not only possible differences in average trends, but also differences in size variability within and outside the MPA. To this end, we performed a first ANCOVA of the median $L$ with location (in/out) as a fixed factor and $T P$ as a covariate, and a second one with interquartile range (IQR) of $L$ as the dependent variable. To allow the comparison of body size trends inside and outside the MPA over consistent time periods, the ANCOVA was performed only on the years in which data were collected in both locations, i.e. 1998-2002 and 2004-2005 (in 1997 and 2006-2007 sampling was conducted only within the MPA, while in 2003 no sampling was made). In order to avoid possible biases caused by their displacement, recaptured individuals (which were released in the centre of the MPA after marking) were not considered in the analysis of body size trends.

\subsection{Body growth}

In crustaceans, body growth is not always characterized by asymptotic patterns (Verdoit et al., 1999). To fit lobster growth in a realistic way, we used a generalized form of the classical von Bertalanffy growth model (VBGM):

$$
\frac{\mathrm{d} L}{\mathrm{~d} t}=a+b L
$$

where $a$ and $b$ are parameters that can define different growth patterns. In particular, if $b<0$ Eq. (1) is equivalent to the VBGM, where $a$ and $b$ can be substituted with the more familiar parameters $L_{\infty}$ $(=-a / b)$ and $k(=-b)$; if $b=0$, body growth is linear and characterized by a constant growth rate equal to $a$; if $b>0$, body growth follows an exponential growth pattern, with growth rate increasing linearly over time. To estimate parameters $a$ and $b$ from available mark-recapture data, we integrated Eq. (1) over the time interval $\Delta t$ elapsed since release at marking. Thus, we obtained an estimated length at recapture $\hat{L}_{\mathrm{r}}$ for each individual, to be compared with the relevant observed length at recapture $L_{\mathrm{r}}$. By explicitly integrating Eq. (1) one obtains:

$\hat{L}_{r}=-\frac{a}{b}+\left(L_{m}+\frac{a}{b}\right) \exp (b \Delta t)$

where $L_{m}$ is body length at marking.

To account for inter-individual variability, we adopted a stochastic formulation. Carapace length at recapture $L_{\mathrm{r}}$ was supposed to differ from its expected value $\hat{L}_{\mathrm{r}}$ by a multiplicative error term:

$L_{r}=\hat{L}_{r} \exp \varepsilon$

where $\varepsilon$ is a Gaussian random factor with mean zero and standard deviation $\sigma_{\varepsilon} \sqrt{\Delta t}$, proportional to the squared root of time elapsed since marking. This formulation assumes body growth to be affected by a lognormal noise process with variance increasing with $\Delta t$, i.e. that the following quantities

$e_{i}=\frac{\ln \left(L_{i, r}\right)-\ln \left(\hat{L}_{i, r}\right)}{\sqrt{\Delta t_{i}}}$

have a Gaussian distribution with mean $=0$ and standard deviation $=\sigma_{\varepsilon}$ (an assumption that has been efficiently used for other aquatic organisms, e.g. Melià et al., 2004), where $L_{i, r}$ and $\hat{L}_{i, r}$ are observed and estimated body size at recapture of the $i$ th individual, and $\Delta t_{i}$ is time elapsed since release.
Model calibration was thus based on minimizing the following cost function:

$J(a, b)=\sum_{i} \frac{\left[\ln \left(L_{i, r}\right)-\ln \left(\hat{L}_{i, r}\right)\right]^{2}}{\sqrt{\Delta t_{i}}}$

The parameter pair $(a, b)$ minimizing $J$ was found with the Nelder-Mead simplex algorithm (Nelder and Mead, 1965). The relevant estimate of $\sigma_{\varepsilon}$ was calculated as the standard deviation of vector $e$ (Eq. (4)). Parameter uncertainty was assessed via stratified bootstrapping (Efron and Tibshirani, 1993). The original data set was subdivided into 20 -mm classes, encompassing different length ranges for females (40-120 mm) and males (60-140 mm) and consisting, on average, of $c a .30$ individuals per class. Data from each class were resampled 1000 times to derive empirical probability distributions for each parameter. Confidence intervals were calculated with the percentile method (Efron and Tibshirani, 1993). To account for sexual dimorphism, body growth was assessed separately for males and females.

\subsection{Mortality rates}

Under the assumption that a population remains stationary (i.e. there is a balance between recruitment, mortality, and immigration/emigration), mortality rate $(Z)$ can be estimated by fitting the exponentially declining right-hand side of the age frequency curve (the well-known age frequency method; see Sparre and Venema, 1998 for details). On the other hand, if a population is increasing or decreasing with a population growth rate $r \neq 0$, the proportion of individuals in a given age class $x$ is proportional, if the population has reached its stable age distribution, to the product $l_{x} \exp (-r x)$, where $l_{x}$ is the proportion of survivors at age $x$ from an original cohort (Pielou, 1977). Hence, even if the hypothesis of stationary population is relaxed and substituted with that of stable age distribution, the age frequency method can still be used. It provides the sum of mortality and population growth rate, $Z+r$, instead of $Z$. Data on catch per unit effort (CPUE) reported by Follesa et al. (2008) for the period 1998-2005 were used to estimate the population growth rate $r$ inside and outside the MPA. In exploited populations, total mortality $Z$ is the sum of natural $(M)$ and fishing mortality $(F)$ rates. The presence of the MPA allows the two effects to be decoupled. Within the MPA, lobsters are affected only by natural mortality, allowing the estimation of $M$. On the other hand, lobsters outside the MPA are subject to both mortality sources. Hence, fitting their age distribution allows the estimation of $Z$ and (under the assumption that natural mortality does not significantly differ inside and outside the MPA) of $F$, which is given by the difference $Z-M$. If dispersal rates from the MPA to outside and from outside to the MPA do not balance out, the estimate of mortality rate would include also the contribution of the net emigration rate (i.e. the difference between emigration and immigration). However, available data did not allow us to discriminate between the effect of mortality and that of dispersal on the age frequency curves from inside and outside the MPA.

Due to the absence of reliable age markers in crustaceans, the age frequency method cannot be applied straightforwardly to lobster populations. However, the body growth model provides a tool to derive age distribution from the observed size distribution. According to the stochastic nature of the model, different ages can be associated to a given body length. By integrating Eq. (1) over age one can express, after some algebra, the age $x$ of an individual with body length $L$ as

$x=\frac{\ln (a+b L / \exp \varepsilon)-\ln \left(a+b L_{0}\right)}{b}$ 

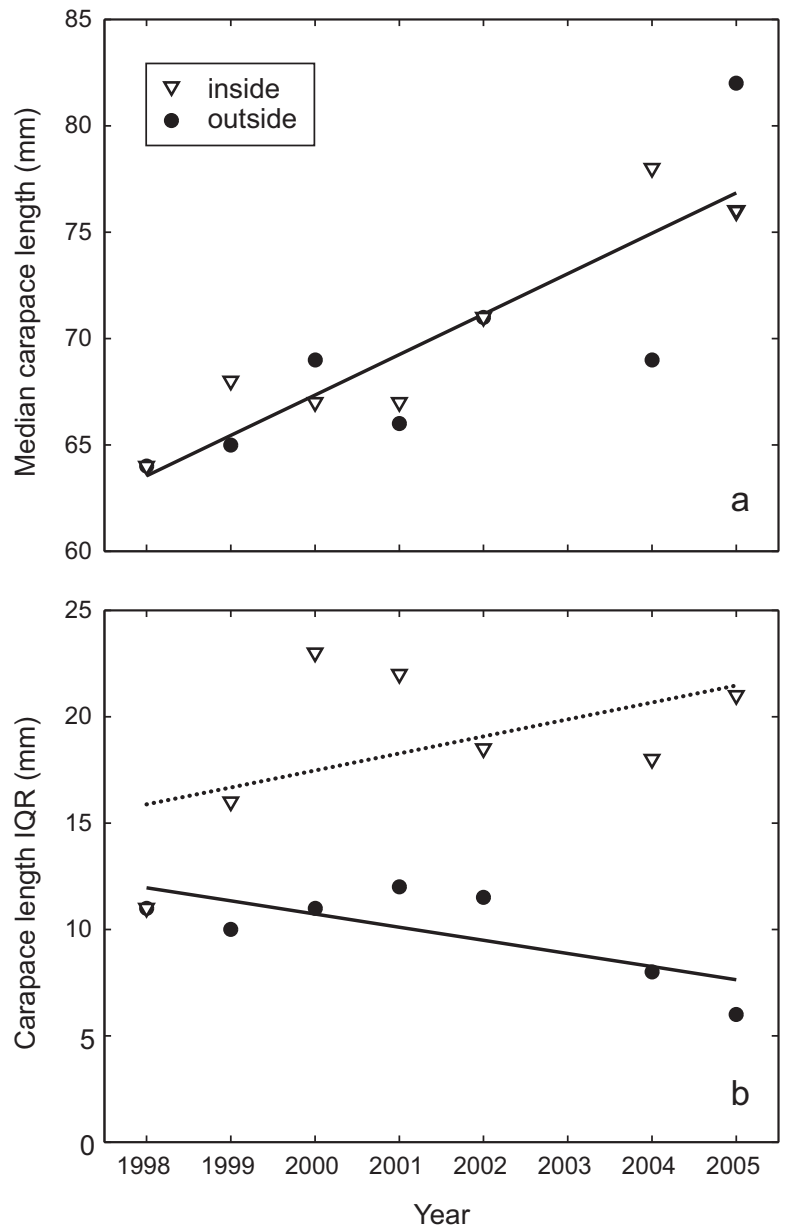

Fig. 2. Analysis of covariance of (a) median and (b) interquartile range of carapace length for Palinurus elephas inside and outside Su Pallosu marine protected area with location (in/out) as a factor and time of protection (since the establishment of the MPA) as a covariate. A single regression line is shown in panel a), indicating that the effect of location is not significant (see text for details).

where $L_{0}$ is carapace length at age 0 [here assumed to be $8.5 \mathrm{~mm}$ according to Marin (1985) and Diaz et al. (2001)] and $\varepsilon$ is the multiplicative noise term, introduced in Eq. (3). To estimate mortality rates, we applied the following procedure: (1) for each individual of the sample, we extracted a value of $\varepsilon$ from a probability distribution with mean $=0$ and standard deviation $=\sigma_{\varepsilon} ;(2)$ we used that value, together with the carapace length $L$ of the same individual at first capture, to estimate the corresponding age $x$ via Eq. (6); (3) after assigning an age to all individuals, we built the empirical age distribution of the sample; (4) we used that age distribution to estimate mortality with the age frequency method. We repeated steps (1)-(4) $1000 \times$ to associate a probability distribution to the estimate.

\section{Results}

\subsection{Body size trends}

When Su Pallosu MPA was established, in 1998, the body size structure of lobsters was the same inside and outside the MPA, with a median carapace length $L$ of $64 \mathrm{~mm}$ and an IQR of $11 \mathrm{~mm}$. Since MPA implementation, body size structure varied significantly (Fig. 2). ANCOVA of median $L$ with location (in/out) as a factor and $T P$ as a covariate (Fig. 2(a)) showed no significant interaction between $T P$ and location $\left(F_{3,10}=0.01 ; p>0.20\right)$ and no significant

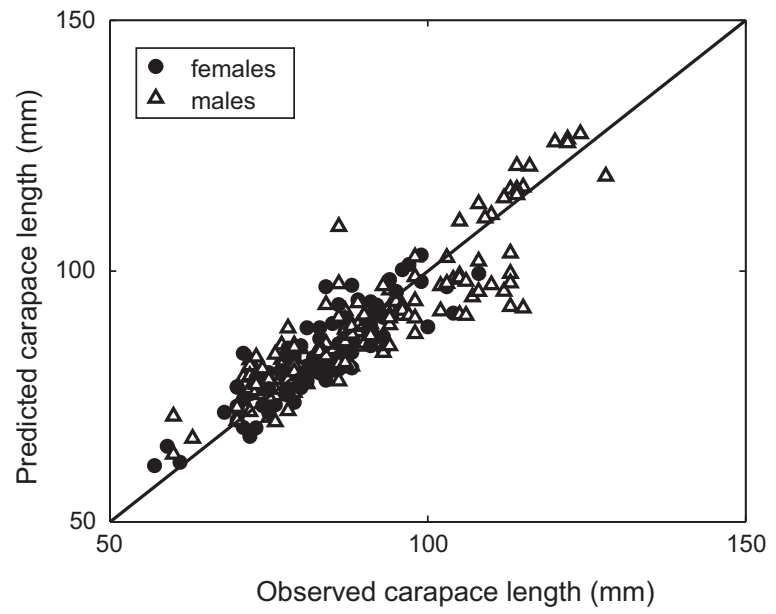

Fig. 3. Comparison between observed and predicted carapace length of Palinurus elephas inside and outside Su Pallosu MPA.

difference in trends between locations $\left(F_{2,11}=0.21 ; p>0.20\right)$, while the effect of TP was positive and highly significant $\left(F_{1,12}=35.0\right.$; $p<0.01$ ) with median $L$ increasing, on average, by $1.9 \mathrm{~mm}$ per year between 1998 and 2005. On the other hand, a significant interaction between TP and location affected body size variability in the same period (Fig. 2(b)), with carapace length IQR increasing by $0.9 \mathrm{~mm}$ per year inside the MPA and decreasing $0.6 \mathrm{~mm}$ per year in the adjacent fishing grounds $\left(F_{3,10}=2.10 ; p<0.1\right)$. Differences between locations were also very clear with respect to the percentage of individuals larger than the minimum legal size in force during the study period ( $L>80 \mathrm{~mm}$ : $33 \%$ inside and only $4 \%$ outside, where no individual $>100 \mathrm{~mm}$ was ever fished).

\subsection{Body growth}

Basic statistics for model parameters are given in Table 2. The classical VBGM provided the best match to observed length increments. Coefficient $b$ (Eq. (1)) was indeed negative in all bootstrap iterations. Fig. 3 compares observed versus predicted $L$ at recapture as obtained with Eq. (2) by setting model parameters to the median value of the relevant bootstrap distributions, and evidences the good predictive performances of the models $\left(R^{2}=0.75\right.$ for females and $R^{2}=0.79$ for males). Estimates of $\sigma_{\varepsilon}$ obtained from Eq. (5) are reported in Table 2 and indicate a higher inter-individual variability in males rather than females. The stochastic model (Eq. (3)) was run over 15 years to generate, through Monte Carlo simulation, the average body growth curves along with their associated probability distributions. Results are shown in Fig. 4. On average, males grow faster than females and attain a bigger body size. This is also confirmed by the growth performance index $\Phi=\log _{10} k+2 \log _{10} L_{\infty}$ (Munro and Pauly, 1983), which was higher in males than in females (3.5 vs. 3.3).

\subsection{Mortality rates}

Age frequencies and their variability, obtained via Eq. (6), are shown in Fig. 5 along with the relevant fitting curves. Population growth rates $r$, estimated through log-linear regression on CPUE data, were 0.14 year $^{-1}$ and 0.08 year $^{-1}$ inside and outside the MPA, respectively. The resulting estimate of mortality rate within the MPA (providing an estimate of natural mortality $M$, inclusive of the net contribution of dispersal) was 0.27 year $^{-1}$ (95\% C.I.: $0.24-0.31$ year $^{-1}$ ) corresponding to an annual survival probability $=76 \%$. The estimated mortality rate outside the MPA (providing an estimate of total mortality $Z$, inclusive of dispersal) 
Table 2

Basic statistics of Palinurus elephas body growth parameters (Eq. (1)), as obtained by bootstrap calibration on the 1997-2007 dataset. $\sigma_{\varepsilon}$ : standard deviation of residuals as from Eq. (4).

\begin{tabular}{|c|c|c|c|c|c|c|}
\hline & \multirow[t]{2}{*}{ Units } & \multirow[t]{2}{*}{ Exp. value \pm SD } & \multirow[t]{2}{*}{ Median } & \multicolumn{2}{|c|}{ Percentiles } & \multirow[t]{2}{*}{ SD of residuals } \\
\hline & & & & 2.5 th & 97.5th & \\
\hline \multicolumn{7}{|c|}{ Females } \\
\hline$a$ & $\left(\mathrm{~mm}_{\mathrm{year}}{ }^{-1}\right)$ & $18.2 \pm 2.1$ & 18.2 & 14.4 & 22.3 & \\
\hline$b$ & $\left(\right.$ year $\left.^{-1}\right)$ & $-0.16 \pm 0.03$ & -0.16 & -0.21 & -0.11 & \\
\hline$L_{\infty}$ & $(\mathrm{mm})$ & $117 \pm 7$ & 116 & 106 & 134 & \\
\hline$k$ & $\left(\right.$ year $\left.^{-1}\right)$ & $0.16 \pm 0.03$ & 0.16 & 0.11 & 0.21 & \\
\hline$\sigma_{\varepsilon}$ & $\left(\right.$ year $\left.^{-0.5}\right)$ & & & & & $2.2 \times 10^{-3}$ \\
\hline \multicolumn{7}{|c|}{ Males } \\
\hline$a$ & $\left(\right.$ mm year $\left.^{-1}\right)$ & $17.7 \pm 1.5$ & 17.8 & 14.8 & 20.6 & \\
\hline$b$ & $\left(\right.$ year $\left.^{-1}\right)$ & $-0.10 \pm 0.02$ & -0.10 & -0.13 & -0.06 & \\
\hline$L_{\infty}$ & $(\mathrm{mm})$ & $189 \pm 24$ & 185 & 155 & 247 & \\
\hline$k$ & $\left(\right.$ year $\left.^{-1}\right)$ & $0.10 \pm 0.02$ & 0.10 & 0.06 & 0.13 & \\
\hline$\sigma_{\varepsilon}$ & $\left(\right.$ year $\left.^{-0.5}\right)$ & & & & & $2.8 \times 10^{-3}$ \\
\hline
\end{tabular}

was 0.70 year $^{-1}$ (95\% C.I.: $0.65-0.75$ year $^{-1}$ ) corresponding to an annual survival probability $=50 \%$. The resulting estimate of fishing mortality was $F=Z-M=0.43$ year $^{-1}$.

\section{Discussion}

Our results show that lobster size structure within Su Pallosu MPA changed over time in a significantly different way from that in the adjacent fishing area, suggesting that MPA protection of larger individuals has been effective and corroborating the idea that even small MPAs can produce significant biological responses (Lester et al., 2009). Average carapace length of lobsters caught in the fishing grounds surrounding Su Pallosu (66 and $67 \mathrm{~mm}$ for females and males, respectively) is very close to that reported by Tidu et al. (2004) in another Mediterranean fishing area (68 and $71 \mathrm{~mm}$ ). In contrast, sizes observed by Goñi et al. (2001) in a $14 \mathrm{~km}^{2}$ MPA in the western Mediterranean were bigger (86 and $110 \mathrm{~mm}$ for females and males, respectively) than within Su Pallosu MPA $(68$ and $73 \mathrm{~mm})$. Although recent studies indicate that $P$. elephas undertakes limited movements, ca. $2.5 \mathrm{~km}$ year $^{-1}$ (Goñi et al., 2006; Follesa et al., 2009), it should be noted that the maximum distance from the centre of Su Pallosu to the MPA boundary is only $1.44 \mathrm{~km}$. Therefore, adult spillover favoured by the small dimensions of Su Pallosu MPA $\left(<4 \mathrm{~km}^{2}\right)$ might have blurred the effect of protection on body size within the MPA. Also, the increase in mean body size caused by the protection of larger individuals may have

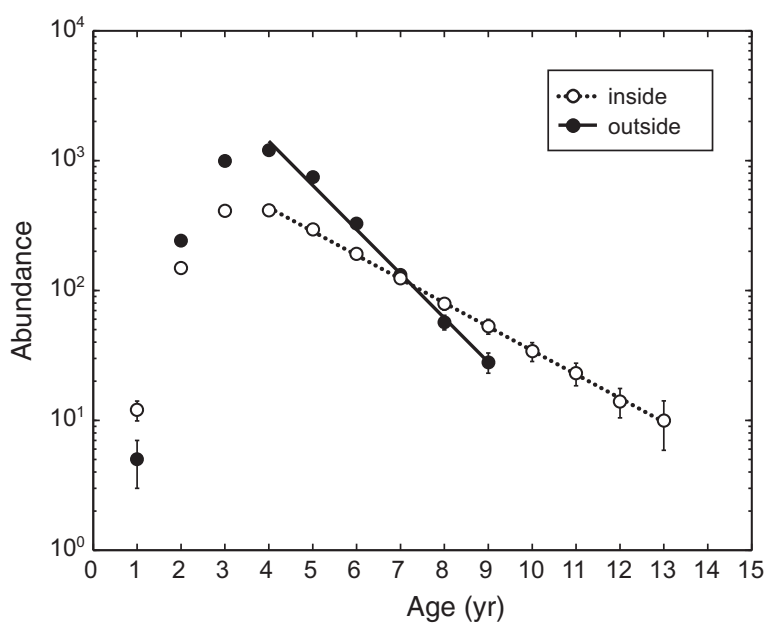

Fig. 5. Estimated age distributions (median values and $90 \%$ confidence intervals) of Palinurus elephas inside and outside Su Pallosu MPA along with relevant fitting lines ( $y$-axis in log-scale).

been reduced by the increasing presence of juveniles, as suggested by higher body size variability within the MPA. In any case, average lobster size at Su Pallosu might keep increasing in the coming years (as observed in other long-term studies on MPAs: e.g., Claudet et al.,
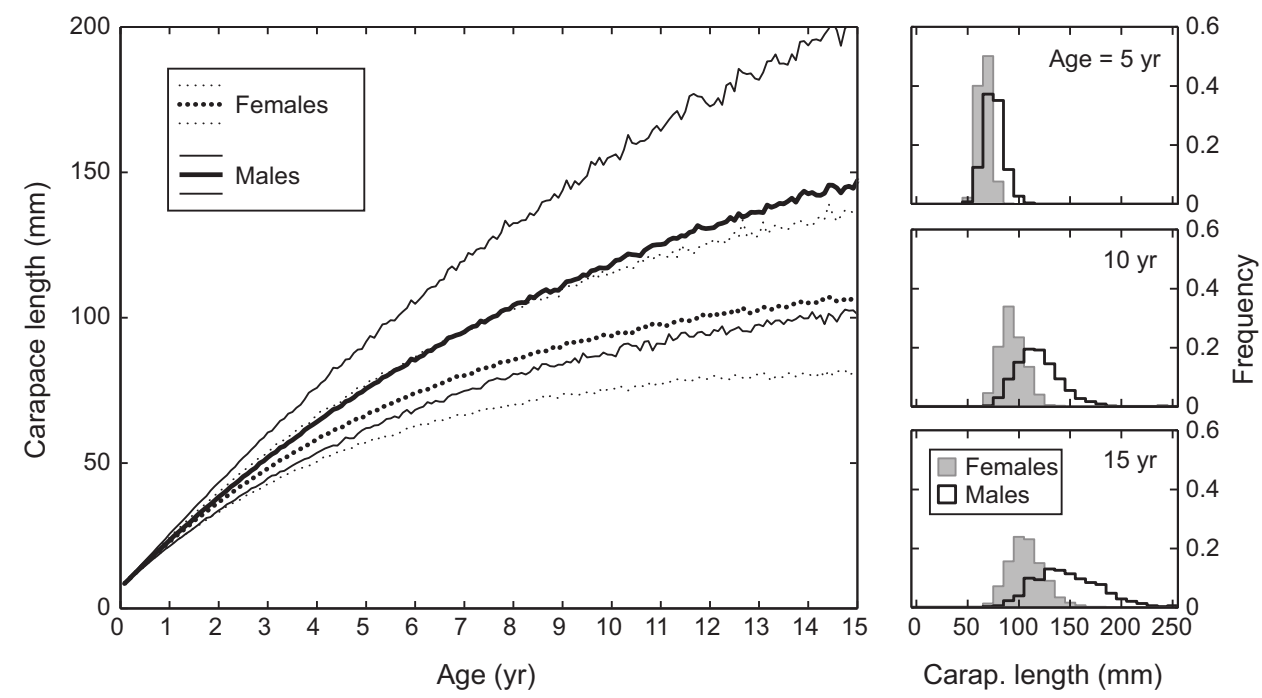

Fig. 4. Simulated body growth of Palinurus elephas obtained by Monte-Carlo simulation ( 1000 iterations of 15 years duration with carapace length $=8.5$ mm at age 0$)$. Thick lines: median value; thin lines: $90 \%$ confidence intervals. The small panels on the right show the size distribution at three representative ages (5, 10 and 15 years). 
2008; Stobart et al., 2009) and eventually attain values similar to those observed by Goñi et al. (2001). The recovery time of protected species has important implications for the assessment of MPA efficacy and the management of surrounding fisheries (McClanahan et al., 2007). For instance, Pande et al. (2008) found that the response of rock lobster body size requires on average 8.5 year since the establishment of an MPA to become fully apparent. Our results suggest that for long-living species, such as P. elephas, a 10-year horizon can provide only partial evidence of the benefits of an MPA.

The long-term mark-recapture experiment provided valuable information on somatic growth in P. elephas. Marked individuals were always released in the MPA centre, irrespective of the capture location, with the aim to increase recapture probability. This experimental design might, in principle, have influenced vital traits such as body growth or survival, due to increased lobster density within the MPA. However, the low recapture rates observed during the study period (Table 1 ) suggest that the displacement of some individuals from outside to inside the MPA has likely had only a minor effect on local lobster abundance. The adequacy of the VBGM to model body growth in aquatic organisms has been questioned by several authors (Katsanevakis and Maravelias, 2008). In fact, non-asymptotic growth patterns have been observed in a number of fish (Curtis and Shima, 2005) and aquatic invertebrates (e.g. Jackson and Choat, 1992; Semmens et al., 2004). For this reason, we used a more general growth model (Eq. (1)), including the VBGM as a special case. Our results indicate that the VBGM provides a satisfactory description of body growth in $P$. elephas. As expected, the model predicts, on average, higher growth rates in males than in females. Sexual dimorphism is indeed common in lobsters (Goñi and Latrouite, 2005), as reproductive females allocate a significant amount of energy in reproduction, while males grow at a sustained rate after sexual maturity. Up to now, studies on body growth of $P$. elephas have been very few (Hepper, 1977; Marin, 1985; Follesa et al., 2007b) and none of them has explicitly considered variation among individuals. However, inter-individual variability affects a number of vital traits (including morphological, physiological and behavioural life history features), with important consequences for population dynamics, stability and persistence (Filin and Ovadia, 2007). Incorporating body growth variability into demographic models is important to provide realistic recruitment estimates and reliable MPA assessments (Pitchford et al., 2007; De Leo et al., 2009).

The method proposed here to assess mortality rates is a modification of the standard method based on age frequency distributions, which may prove particularly helpful for organisms lacking reliable age markers such as crustaceans. Combined with a nonparametric approach based on stratified bootstrapping, it provides also a powerful tool to assess the uncertainty associated to parameter estimates. Resulting estimates of natural mortality $M$ for $P$. elephas (ranging between 0.24 and 0.31 year $^{-1}$ ) can be compared with those obtained in previous studies on other Mediterranean populations. They overlap with the range $\left(0.15-0.30\right.$ year $\left.^{-1}\right)$ proposed by Marin (1987) on the basis of speculative arguments and, partially, with that (0.14-0.26 year $^{-1}$ ) derived by Goñi et al. (2010) through a modelling approach. In contrast, they are considerably higher than the point estimate $\left(0.11\right.$ year $\left.^{-1}\right)$ obtained by Hepper (1977) with tag-recapture experiments in Atlantic populations. The discrepancy between those figures and ours might be due to actual differences in mortality rates between regions (Atlantic $v s$. Mediterranean), to differences in methodological assumptions, or to the bias caused by the effect of lobster dispersal. As for possible geographical differences, mortality rates are indeed known to increase non-linearly with water temperature in a wide range of aquatic organisms (McCoy and Gillooly, 2008; Bevacqua et al., 2010). With respect to methodology, it should be noted that our estimates have been derived under the hypothesis that the lobster population has reached its stable age distribution. The hypothesis might be quite far from being met, because the age structure might be still shifting towards older age classes following the closure of the fishery. The transient from an age structure shaped by fishing mortality to one determined only by natural mortality is possibly further delayed by the immigration from the fishing grounds to the MPA. As for the effect of lobster dispersal, it should be noted that our estimate of $M$ encompasses the effect of spillover from the MPA, and may therefore overestimate the actual natural mortality rate within the range of protection. On the other hand, the effect of spillover on the estimation of total mortality $Z$ in the fishing grounds may have caused a slight underestimation of this parameter and, consequently, of fishing mortality $F$ (calculated as the difference $Z-M$ ). Finally, the assumption that natural mortality is not significantly different inside and outside the MPA would be violated if a higher density of predators determined a higher rate of natural mortality within the MPA (see, e.g., Diaz et al., 2005), causing a further underestimation of fishing mortality. For these reasons, our estimate of $F$ should be considered as a conservative evaluation of the actual pressure exerted by fishermen. Although dedicated studies focusing on the dispersal of lobsters across the MPA boundaries and on the ecological interactions involving lobsters and predatory fish species benefiting from the MPA would be highly desirable to refine the assessment of mortality rates, we are confident that the methodology proposed here represents an improvement over other techniques commonly used in stock assessment, which are often based on more stringent hypotheses (such as population stationarity).

\section{Acknowledgements}

We are grateful to P. Guidetti and A.J. Haupt for valuable comments on the manuscript draft.

\section{References}

Bevacqua, D., Melià, P., De Leo, G.A., Gatto, M., in press. Intra-specific scaling of natural mortality in fish: the paradigmatic case of the European eel. Oecologia, doi:10.1007/s00442-010-1727-9.

Caswell, H., 1989. Matrix Population Models: Construction, Analysis and Interpretation. Sinauer Associates, Sunderland.

Claudet, J., Osenberg, C.W., Benedetti-Cecchi, L., Domenici, P., García-Charton, J.A., Pérez-Ruzafa, A., Badalamenti, F., Sempere, J.B., Brito, A., Bulleri, F., Culioli, J.M., Dimech, M., Falcon, J.M., Guala, I., Milazzo, M., Sanchez-Meca, J., Somerfield, P.J. Stobart, B., Vandeperre, F., Valle, C., Planes, S., 2008. Marine reserves: size and age do matter. Ecol. Lett. 11, 481-489.

Curtis, T.D., Shima, J.S., 2005. Geographic and sex-specific variation in growth of yellow-eyed mullet, Aldrichetta forsteri, from estuaries around New Zealand. N. Z. J. Mar. Freshw. Res. 39, 1277-1285.

De Leo, G.A., Melià, P., Gatto, M., Crivelli, A.J., 2009. Eel population modeling and its application to conservation management, in eels at the edge: science, status, and conservation concerns. In: Casselman, J.M., Cairns, D.K. (Eds.), American Fishery Society Symposium, vol. 58, pp. 329-347.

Diaz, D., Mari, M., Abello, P., Demestre, M., 2001. Settlement and juvenile habitat of the European spiny lobster Palinurus elephas (Crustacea: Decapoda: Palinuridae) in the western Mediterranean Sea. Sci. Mar. 65, 347-356.

Diaz, D., Zabala, M., Linares, C., Hereu, B., 2005. Increased predation of juvenile European spiny lobster (Palinurus elephas) in a marine protected area. N.Z. J. Mar. Freshw. Res. 39, 447-453.

Edgar, G.J., Barret, N.S., 1999. Effects of the declaration of marine reserves on Tasmanian reef fishes, invertebrates and plants. J. Exp. Mar. Bio. Ecol. 242, 107-144.

Efron, B., Tibshirani, R., 1993. An Introduction to the Bootstrap. Chapman and Hall, London.

Filin, I., Ovadia, O., 2007. Individual size variation and population stability in a seasonal environment: a discrete-time model and its calibration using grasshoppers. Am. Nat. 170, 719-733.

Follesa, M.C., Cuccu, D., Cannas, R., Sabatini, A., Cau, A., 2007a. Emigration and retention of Palinurus elephas (Fabricins, 1787) in a central western Mediterranean marine protected area. Sci. Mar. 71, 279-285.

Follesa, M.C., Cuccu, D., Cannas, R., Cau, A., 2007b. On the growth of the European spiny lobster, Palinurus elephas from Sardinian waters (central western Mediterranean Sea). N.Z. J. Mar. Freshw. Res. 41, 377-383.

Follesa, M.C., Cuccu, D., Cannas, R., Cabiddu, S., Murenu, M., Sabatini, A., Cau, A., 2008. Effects of marine reserve protection on spiny lobster (Palinurus elephas Fabr., 1787 ) in a central western Mediterranean area. Hydrobiologia 606, 63-68. 
Follesa, M.C., Cuccu, D., Cannas, R., Sabatini, A., Deiana, A.M., Cau, A., 2009. Movement patterns of the spiny lobster Palinurus elephas (Fabricius, 1787) from a central western Mediterranean protected area. Sci. Mar. 73, 499-506.

Goñi, R., Reñones, O., Quetglas, A., 2001. Dynamics of a protected Western Mediterranean population of the European spiny lobster Palinurus elephas (Fabricius, 1787) assessed by trap surveys. Mar. Freshw.Res. 52, 1577-1587.

Goñi, R., Quetglas, A., Reñones, O., 2003. Size at maturity, fecundity and reproductive potential of a protected population of the spiny lobster Palinurus elephas (Fabricius, 1787) from the western Mediterranean. Mar. Biol. 143, 583592.

Goñi, R., Latrouite, D., 2005. Review of the biology, ecology and fisheries of Palinurus spp. species of European waters: Palinurus elephas (Fabricius, 1787) and Palinurus mauritanicas (Gruvel, 1911). Cah. Biol. Mar. 46, 127-142.

Goñi, R., Quetglas, A., Reñones, O., 2006. Spillover of spiny lobsters Palinurus elephas from a marine reserve to an adjoining fishery. Mar. Ecol. Prog. Ser. 308, 207-219.

Goñi, R., Adlerstein, S., Alvarez-Berastegui, D., Forcada, A., Reñones, O., Criquet, G., Polti, S., Cadiou, G., Valle, Lenfant P., Bonhomme, P., Pérez-Ruzafa, A., SánchezLizaso, J.L., García-Charton, A.J.A., Bernard, J., Stelzenmüller, V., Planes, S., 2008. Spillover from six western Mediterranean marine protected areas: evidence from artisanal fisheries. Mar. Ecol. Prog. Ser. 366, 159-174.

Goñi, R., Hilborn, R., Diaz, D., Mallol, S., Alderstein, S., 2010. Net contribution of spillover from a marine reserve to fishery catches. Mar. Ecol. Prog. Ser. 400, 233-243.

Halpern, B.S., 2003. The impact of marine reserves: do reserves work and does reserve size matter? Ecol. Appl. 13, S117-S137.

Hepper, B.T., 1977. The fishery for crawfish, Palinurus elephas, off the cost of Cornwall. J. Mar. Biolog. Assoc. U. K. 57, 925-941.

Hunter, E., 1999. Biology of the European spiny lobster, Palinurus elephas (Fabricius, 1787) (Decapoda, Palinuridea). Crustaceana 72, 545-565.

Jackson, G.D., Choat, J.H., 1992. Growth in tropical cephalopods - an analysis based on statolith microstructure. Can. J. Fish. Aquat. Sci. 49, 218-228.

Katsanevakis, S., Maravelias, C.D., 2008. Modelling fish growth: multi-model inference as a better alternative to a priori using von Bertalanffy equation. Fish Fish. 9, 178-187.

Lester, S.E., Halpern, B.S., Grorud-Colvert, K., Lubchenco, J., Ruttenberg, B.I., Gaines, S.D., Airame, S., Warner, R.R., 2009. Biological effects within no-take marine reserves: a global synthesis. Mar. Ecol. Prog. Ser. 384, 33-46.

Marin, J., 1985. Etude de la croissance des Crustacés à partir des données de marquages-recaptures. Application à la langouste rouge de Corse, Palinurus elephas Fabricius. C.I.E.M. C.M., K:26, pp. 1-17.

Marin, J., 1987. Exploitation, biologie et dynamique du stock de langouste rouge de Corse, Palinurus elephas Fabricius. PhD Dissertation, Université de Aix, Marseille.

McClanahan, T.R., Graham, N.A.J., Calnan, J.M., MacNeil, M.A., 2007. Toward pristine biomass: reef fish recovery in coral reef marine protected areas in Kenya. Ecol. Appl. 17, 1055-1067.
McCoy, M.W., Gillooly, J.F., 2008. Predicting natural mortality rates of plants and animals. Ecol. Lett. 11, 710-716.

Melià, P., De Leo, G.A., Gatto, M., 2004. Density and temperature-dependence of vital rates in the Manila clam Tapes philippinarum: a stochastic demographic model. Mar. Ecol. Prog. Ser. 272, 153-164.

Micheli, F., Halpern, B.S., Botsford, L.W., Warner, R.R., 2004. Trajectories and correlates of community change in no-take marine reserves. Ecol. Appl. 14, 1709-1723.

Munro, J.L., Pauly, D., 1983. A simple method for comparing the growth of fish and invertebrate. Fishbyte 1, 5-6.

Nelder, J.A., Mead, R., 1965. A simplex method for function minimization. Comp. J. 7, 308-313.

Pande, A., MacDiarmid, A.B., Smith, P.J., Davidson, R.J., Cole, D., Freeman, S., Kelly, S., Gardner, G.P.A., 2008. Marine reserves increase the abundance and size of blue cod and rock lobster. Mar. Ecol. Prog. Ser. 366, 147-158.

Pauly, D., Christensen, V., Guenette, S., Pitcher, T.J., Sumalia, U.R., Waters, C.J., Watson, R., Zeller, D., 2002. Towards sustainability in world fisheries. Nature 418 , 689-695.

Pielou, E.C., 1977. Mathematical Ecology. Wiley, New York.

Pitchford, J.W., Codling, E.A., Psarra, D., 2007. Uncertainty and sustainability in fisheries and the benefit of marine protected areas. Ecol. Modell. 207, 286-292.

Russ, G.R., Stockwell, B., Alcala, A.C., 2005. Inferring versus measuring rates of recovery in no-take marine reserves. Mar. Ecol. Prog. Ser. 292, 1-12.

Semmens, J.M., Pecl, G.T., Villanueva, R., Jouffre, D., Sobrino, I., Wood, J.B., Rigby, P.R., 2004. Understanding octopus growth: patterns, variability and physiology. Mar. Freshw.Res. 55, 367-377.

Smith, I.P., Jensen, A.C., Collins, K.J., Mattey, E.L., 2001. Movement of wild European lobsters Homarus gammarus in natural habitat. Mar. Ecol. Prog. Ser. 222, 177-186.

Sparre, P., Venema, S. C. 1998. Introduction to tropical fish stock assessment. Part 1. Manual. Rev. 2. FAO. Fish. Tech. Pap. 306/1. FAO, Rome.

Stelzenmüller, V., Maynou, F., Martin, P., 2007. Spatial assessment of benefits of a coastal Mediterranean marine protected area. Biol. Cons. 136, 571-583.

Stobart, B., Warwick, R., González, C., Mallol, S., Díaz, D., Reñones, O., Goñi, R., 2009 Long-term and spillover effects of a marine protected area on an exploited fish community. Mar. Ecol. Prog. Ser. 384, 47-60.

Tidu, C., Sardà, R., Pinna, M., Cannas, A., Meloni, M.F., Lecca, E., Savarino, R., 2004. Morphometric relationships of the European spiny lobster Palinurus elephas from northwestern Sardinia. Fish. Res. 69, 371-379.

Ulmestrand, M., Eggert, H., 2001. Growth of Norway lobster, Nephrops norvegicus (Linnaeus 1758), in the Skagerrak, estimated from tagging experiments and length frequency data. ICES J. Mar. Sci. 58, 1326-1334.

Verdoit, M., Pelletier, D., Talidec, C., 1999. A growth model that incorporates individual variability for the Norway lobster population (Nephrops norvegicus, L-1758) from the bay of Biscay. ICES J. Mar. Sci. 56, 734-745. 